\title{
EFFECT OF SPECIES ON MACRO AND MICRO MINERAL COMPOSITION OF SOME SHRUB LEAVES WITH RESPECT TO SHEEP REQUIREMENTS
}

\author{
Adem KAMALAK ${ }^{1}$, Çağrı Özgür ÖZKAN ${ }^{*}$, Kadir YILMAZ² \\ ${ }^{1}$ Department of Animal Science, Faculty of Agriculture, University of Kahramanmaras Sutcu Imam, 46000, Kahramanmaras, Turkey \\ 2 Department of Soil Science, Faculty of Agriculture, University of Kahramanmaras Sutcu Imam, 46000, Kahramanmaras, Turkey
}

\begin{abstract}
The purpose of the study was to evaluate the effect of species on the macro and mineral profiles of some shrub leaves used for small ruminant animals in Turkey. Species had a significant effect on the macro and micro mineral profiles of shrub laeves. Calcium (Ca) contents of forages varied from 5.6 to $21.2 \mathrm{~g} / \mathrm{kg}$ DM, with highest being for Rosa canina and lowest for Arbutus andrachne and Quercus coccifera. Phosphorus (P) contents of shrub leaves ranged from 1.1 to $2.1 \mathrm{~g} / \mathrm{kg}$ DM with highest being for Arbutus unedo and Rosa canina and the lowest for Arbutus andrachne. The magnesium (mg) content of forages ranged from 1.9 to $5.5 \mathrm{~g} / \mathrm{DM}$, with the highest being for Pistacia lentiscus and the lowest for Quercus coccifera. The potassium (K) content of forages ranged from 4.1 to 10.3 $\mathrm{g} / \mathrm{kg}$ DM. The K contents of Pistacia lentiscus and Arbutus unedo were significantly higher than the other shrub leaves. The iron (Fe) content of shrub leaves ranged from 105.2 to $458.5 \mathrm{mg} / \mathrm{kg}$ DM. The Fe content of Pistacia lentiscus was significantly higher than the other shrub leaves. The zinc (Zn) contents of shrub leaves ranged from 15.5 to $36.0 \mathrm{mg} / \mathrm{kg}$ DM. The $\mathrm{Zn}$ content of Quercus coccifera was significantly higher than the other shrubs. Copper (cu) contents of forages varied widely from 3.0 to $6.7 \mathrm{mg} / \mathrm{kg} \mathrm{DM}$, with the highest being for Arbutus unedo and Quercus coccifera. The manganese (Mn) content of forages varied from 10.5 to $113.0 \mathrm{mg} / \mathrm{kg} \mathrm{DM}$, with the highest being for Arbutus unedo and the lowest for Rosmarinus officinalis. As a conclusion, shrubs' leaves have a significant amount of macro and micro minerals to support the growth and production of lamb and sheep, although the shrubs leaves' studied in the current experiment are not adequate to meet the dietary $\mathrm{Cu}$ requirement of lamb and sheep.
\end{abstract}

Keywords: Macro mineral, Micro mineral, Sheep, Shrubs

*Corresponding author: Department of Animal Science, Faculty of Agriculture, University of Kahramanmaras Sutcu Imam, 46000, Kahramanmaras, Turkey

E mail: cagri@ksu.edu.tr (C.. Ö. ÖZKAN)

Adem KAMALAK (iD) https://orcid.org/0000-0003-0967-4821

Çă̆rı Özgür ÖZKAN (iD) https://orcid.org/0000-0003-1752-8293

Kadir YILMAZ (iD) https://orcid.org/0000-0002-0539-4534

Received: January 28, 2022

Accepted: February 11, 2022

Published: April 01, 2022

Cite as: Kamalak A, Özkan ÇÖ, Yllmaz K. 2022. Effect of species on macro and micro mineral composition of some shrub leaves with respect to sheep requirements. BSJ Agri, 5(2): 87-90.

\section{Introduction}

Tree and shrub leaves are very important resources in providing not only energy and protein but also minerals for small ruminant animals in most parts of the world (Theng et al., 2003; Kamalak et al., 2010; Ansah and Nagbila, 2011; Kaya and Kamalak, 2012; Atalay et al., 2017; Mboko et al., 2017; Ziblim et al., 2019). Although there is considerable information about the chemical compositions, digestibility, and metabolisable energy values of tree and shrub leaves (Kamalak et al., 2004; Ozkan and Sahin, 2006; Kilic et al., 2010), the information about the mineral contents of tree and shrub leaves is very limited. Macro and micro minerals may have an important role as structural functions in bones, as electrolytes in body fluids, as integral components of enzymes and other biologically important compounds (Bourne and Orr., 1988). Poor performance in ruminants may be caused by deficiency and excess of minerals (Ozkan et al., 2020)

Information about the macro and micro mineral compositions of shrub leaves from different species can be used to formulate the most accurate diet to achieve the optimum performance of grazing small ruminant animals and prevent diseases associated with mineral deficiency (Khan et al., 2007; Ozkan et al., 2016; Ozkan et al., 2020). Therefore, the aim of the current study was to determine the effect of species on the macro and mineral composition of some shrub leaves used for small ruminant animals in Turkey.

\section{Material and Methods}

\subsection{Forage Samples}

Leaves from Arbutus andrachne, Arbutus unedo, Pistacia lentiscus, Quercus coccifera, Rhus typhina, Styrax officinalis, Glycyrrhiza glabra, Rosa canina, and Rosmarinus officinalis were collected by hand from ten different shrubs in June, 2020, in Kahramanmaras, Turkey. The mean annual rainfall and temperature are $500 \mathrm{~mm}$ and $14.9{ }^{\circ} \mathrm{C}$, respectively. The collected shrub leave samples were pooled and dried under sheds until 


\section{Black Sea Journal of Agriculture}

they reached a constant weight. The soil of the study area is classified as Inceptisols, which was formed on a colluvial serpentine-limestone parent material (Yilmaz et al., 2000). Dried leave samples were ground using a laboratory mill with a $1 \mathrm{~mm}$ screen size for mineral analysis. Leave samples were subjected to a wet-ashing process with hydrogen peroxide, following three different steps. Firstly, the leave samples were kept at $145{ }^{\circ} \mathrm{C}$ at $75 \%$ microwave power for 5 minutes. Second, for 10 minutes, leave samples were kept at $80 \mathrm{oC}$ at $90 \%$ microwave power. Finally, leave samples were kept at $100{ }^{\circ} \mathrm{C}$ with $40 \%$ microwave power for 10 minutes in a wet-ashing unit (speed wave MWS-2 Berghof products + Instruments Harresstr.1. 72800 Enien, Germany) resistant to 40 bar pressure (Mertens, 2005a). After wetashing, macro and micro mineral contents of leave samples were analyzed using Inductively Couple Plasma Optical Emission Spectrophotometer (Perkin-Elmer, Optima 2100 DV, ICP/OES, Shelton, CT 06484-4794, USA) (Mertens, 2005b). All mineral analysis was carried out in duplicate.

\subsection{Statistical Analysis}

One-way analysis of variance (ANOVA) was used to determine the effect of species on the macro and mineral composition of shrub leave samples. Significance between individual means was identified using Tukey's multiple range tests. The mean differences were considered significant at $\mathrm{P}<0.05$.

\section{Result and Discussion}

\subsection{The Effect of Species on Macro Mineral Profile of} Some Shrub Leaves

The macro mineral profiles of some shrub leaves are given in Table 1. Species had a significant effect on the macro mineral profiles of shrub leaves. The Ca content of forages varied from 5.6 to $21.2 \mathrm{~g} / \mathrm{kg} \mathrm{DM}$, with the highest being for Rosa canina and the lowest for Arbutus andrachne and Quercus coccifera. NRC (1985) suggested that Ca contents should be in the range of 0.2 and $0.82 \%$ of DM to meet the requirements of lamb and sheep at gestation and lactation stages respectively. As can be seen from Table 1 the Ca contents of shrub leaves studied in the current experiment were higher than those suggested by NRC (1985) for lambs and sheep at gestation and lactation stages.

The P content of shrub leaves ranged from 1.1 to $2.1 \mathrm{~g} / \mathrm{kg}$ DM, with the highest being for Arbutus unedo and Rosa canina, and the lowest for Arbutus andrachne. NRC (1985) recommended that $P$ content of feedstuffs should be in the range of 0.16 and $0.38 \%$ of DM to meet the requirement of lamb and sheep at most production stages. As can be seen from Table $1 \mathrm{P}$ contents of shrub leaves was significantly higher than those recommended by NRC (1985).

The Mg content of forages ranged from 1.9 to $5.5 \mathrm{~g} / \mathrm{DM}$, with the highest being for Pistacia lentiscus, and the lowest for Quercus coccifera. NRC (1985) recommended that the Mg content of feedstuffs be $0.12,0.15$ and 0.18 $\mathrm{g} / \mathrm{kg}$ DM for growing lambs, pregnant, and lactating ewes, respectively. As can be seen in Table 1, the Mg contents of shrub leaves were higher than those suggested by NRC (1985) for growing lambs, pregnant, and lactating ewes.

The $\mathrm{K}$ content of forages ranged between 4.1 and 10.3 g/kg DM. The K contents of Pistacia lentiscus and Arbutus unedo were significantly higher than the other shrub leaves. Although the K content of diets for lamb growth should be more than $0.5 \%$ of $\mathrm{DM}$, the $\mathrm{K}$ content of diets for lactating sheep should be in the range of 0.7-0.8 percent of DM (NRC 1985). As can be seen in Table 1, the $\mathrm{K}$ contents of shrub leaves were higher than those suggested by NRC (1985) for lamb and sheep.

\subsection{The Effect of Species on Micro Mineral Profile of Some Shrub Leaves}

The micro mineral profiles of shrub leaves are given in Table 2. Species also had a significant effect on the micro mineral profiles of shrub leaves. The Fe content of shrub leaves ranged from 105.2 to $458.5 \mathrm{mg} / \mathrm{kg} \mathrm{DM}$. The Fe content of Pistacia lentiscus was significantly higher than the other shrub leaves.

Table 1. Effect of species on the macro mineral composition (g/kg DM) of shrub leaves $(n=2)$

\begin{tabular}{lcccc}
\hline \multicolumn{4}{c}{ Macro minerals } \\
\hline Shrub species & \multicolumn{1}{c}{$\mathrm{M}$} & $\mathrm{K}$ \\
\hline Arbutus andrachne & $\mathrm{Ca}$ & $\mathrm{P}$ & $3.1^{\mathrm{c}}$ & $5.9^{\mathrm{cd}}$ \\
Arbutus unedo & $5.8^{\mathrm{f}}$ & $1.3^{\mathrm{c}}$ & $2.9^{\mathrm{cd}}$ & $10.0^{\mathrm{a}}$ \\
Pistacia lentiscus & $11.2^{\mathrm{d}}$ & $2.0^{\mathrm{a}}$ & $5.5^{\mathrm{a}}$ & $10.3^{\mathrm{a}}$ \\
Quercus coccifera & $5.6^{\mathrm{f}}$ & $1.0^{\mathrm{d}}$ & $1.9^{\mathrm{e}}$ & $9.2^{\mathrm{ab}}$ \\
Rhus typhina & $5.8^{\mathrm{f}}$ & $1.7^{\mathrm{b}}$ & $2.1^{\mathrm{de}}$ & $7.8^{\mathrm{bc}}$ \\
Styrax officinalis & $17.0^{\mathrm{b}}$ & $1.6^{\mathrm{b}}$ & $4.0^{\mathrm{b}}$ & $7.0^{\mathrm{c}}$ \\
Glycyrrhiza glabra & $13.1^{\mathrm{c}}$ & $1.7^{\mathrm{b}}$ & $3.5^{\mathrm{bc}}$ & $4.1^{\mathrm{d}}$ \\
Rosa canina & $9.5 \mathrm{~d}^{\mathrm{e}}$ & $1.6^{\mathrm{bc}}$ & $3.6^{\mathrm{bc}}$ & $4.2^{\mathrm{d}}$ \\
Rosmarinus officinalis & $21.2^{\mathrm{a}}$ & $2.1^{\mathrm{a}}$ & $4.3^{\mathrm{b}}$ & $4.8^{\mathrm{d}}$ \\
SEM & $8.7^{\mathrm{e}}$ & $1.7^{\mathrm{b}}$ & 0.238 & 0.476 \\
$P$ & 0.515 & 0.061 & $<0.001$ & $<0.001$ \\
\hline
\end{tabular}

abcDifferent letters in same column indicate the statistical difference at $\mathrm{P}<0.05$. SEM= standard error of mean. 
Black Sea Journal of Agriculture

Table 2. Effect of species on the micro mineral composition (g/kg DM) of shrub leaves $(\mathrm{n}=2)$

\begin{tabular}{lcccc}
\hline & \multicolumn{3}{c}{ Micro minerals } \\
\hline Shrub species & Fe & Zn & Cu & Mn \\
\hline Arbutus andrachne & $156.0^{\mathrm{d}}$ & $29.0^{\mathrm{b}}$ & $4 . \mathrm{b}^{\mathrm{c}}$ & $17.2^{\mathrm{de}}$ \\
Arbutus unedo & $242.0^{\mathrm{b}}$ & $18.5^{\mathrm{c}}$ & $6.7^{\mathrm{a}}$ & $113.0^{\mathrm{a}}$ \\
Pistacia lentiscus & $458.5^{\mathrm{a}}$ & $32.0^{\mathrm{b}}$ & $5.0^{\mathrm{ab}}$ & $21.5^{\mathrm{d}}$ \\
Quercus coccifera & $120.7^{\mathrm{e}}$ & $36.0^{\mathrm{a}}$ & $6.7^{\mathrm{a}}$ & $27.7^{\mathrm{c}}$ \\
Rhus typhina & $105.2^{\mathrm{e}}$ & $16.2^{\mathrm{d}}$ & $5.2^{\mathrm{ab}}$ & $19.7^{\mathrm{de}}$ \\
Styrax officinalis & $162.5^{\mathrm{d}}$ & $15.5^{\mathrm{d}}$ & $3.0^{\mathrm{c}}$ & $15.7^{\mathrm{e}}$ \\
Glycyrrhiza glabra & $203.0^{\mathrm{c}}$ & $19.2^{\mathrm{cd}}$ & $4.2^{\mathrm{bc}}$ & $61.5^{\mathrm{b}}$ \\
Rosa canina & $230.2^{\mathrm{b}}$ & $18.0^{\mathrm{cd}}$ & $5.5^{\mathrm{ab}}$ & $29.2^{\mathrm{c}}$ \\
Rosmarinus officinalis & $116.0^{\mathrm{e}}$ & $21.2^{\mathrm{c}}$ & $3.0^{\mathrm{c}}$ & $10.5^{\mathrm{f}}$ \\
SEM & 6.044 & 0.993 & 0.471 & 1.252 \\
$P$ & $<0.001$ & $<0.001$ & $<0.001$ & $<0.001$ \\
\hline
\end{tabular}

abcDifferent letters in same column indicate the statistical difference at $\mathrm{P}<0.05$. SEM= standard error of mean.

NRC (1985) recommended that the Fe content of diets should be $30 \mathrm{mg} / \mathrm{kg}$ DM to meet the Fe requirements for all classes of sheep. On the other hand, a maximum tolerable level of the Fe has been indicated as $500 \mathrm{mg} / \mathrm{kg}$ DM (NRC 1980). As can be seen from Table 2, The Fe contents of shrub leaves studied in the current experiment were higher than the adequate level for sheep but lower than the maximum tolerable level for sheep.

The $\mathrm{Zn}$ content of shrub leaves ranged from 15.5 to 36.0 $\mathrm{mg} / \mathrm{kg}$ DM. The Zn content of Quercus coccifera was significantly higher than the other shrubs. Although the $\mathrm{Zn}$ requirement of lamb for growth is $20 \mathrm{mg} / \mathrm{kg} \mathrm{DM}$, the $\mathrm{Zn}$ requirement of sheep at most production stages is 33 $\mathrm{mg} / \mathrm{kg}$ DM (NRC 1985). Therefore, sheep or lambs consuming these shrubs are not likely to suffer from zinc deficiency.

The $\mathrm{Cu}$ content of forages varied widely from 3.0 to 6.7 $\mathrm{mg} / \mathrm{kg}$ DM, with the highest being for Arbutus unedo, and Quercus coccifera. It is very difficult to determine the dietary $\mathrm{Cu}$ requirement of sheep since there are some factors affecting the dietary copper requirement of sheep. The amount of molybdenum in feedstuffs also effects the dietary $\mathrm{Cu}$ requirement of sheep. The high level of molybdenum in feedstuffs induces copper deficiency. There are also considerable differences among sheep breeds in terms of efficiency in absorbing $\mathrm{Cu}$ from feedstuffs. Even if it is not easy to give the exact dietary $\mathrm{Cu}$ requirement of sheep due to some factors affecting the dietary copper requirement of sheep, NRC (1985) recommended that the $\mathrm{Cu}$ content of diets should be 7-23 $\mathrm{mg} / \mathrm{kg}$ DM to meet the $\mathrm{Cu}$ requirements for all classes of sheep. As can be seen from Table 2, the $\mathrm{Cu}$ content of shrub leaves were lower than those recommended by NRC (1985). Therefore, sheep should be supplemented with $\mathrm{Cu}$ when shrub leaves consists of most part of diets. The Mn content of forages varied from 10.5 to 113.0 mg/kg DM, with the highest being for Arbutus unedo, and the lowest for Rosmarinus officinalis. Although the exact dietary requirement of $\mathrm{Mn}$ for sheep is not known, 20 $\mathrm{mg} / \mathrm{kg}$ DM should be adequate for sheep at most production stages (NRC 1985). Although the Mn contents of most shrubs studied in the current experiment were adequate or considerably higher than the recommended level for sheep at most production stages (NRC 1985), the Mn contents of leaves of Arbutus andrachne, Styrax officinalis, and Rosmarinus officinalis were lower than that recommended by NRC (1985).

\section{Conclusion}

Species had a significant effect on the macro and micro mineral profiles of shrub leaves. Although shrubs leaves studied in the current experiment is not adequate to meet the dietary $\mathrm{Cu}$ requirement of lamb and sheep, shrubs leaves have a significant amount macro and micro minerals to support the growth and production of lamb and sheep.

\section{Author Contributions}

All authors have equal contribution and the authors reviewed and approved the manuscript.

\section{Conflict of Interest}

The authors declared that there is no conflict of interest.

\section{Ethical Approval}

Ethical approval is not required, because this article does not contain any studies with human or animal subjects.

\section{References}

Ansah T, Nagbila DA. 2011. Utilization of local trees and shrubs for sustainable livestock production in the Talensi-Nabdam District of the Upper East Region of Ghana. Livestock Res Rural Devel, 23: 75.

Atalay AI, Ozkan CO, Kaya E, Kurt O, Kamalak A. 2017. Effect of maturity on chemical composition and nutritive value of leaves of Arbutus andrachne shrub and rumen in vitro methane production. Livestock Res Rural Devel, 9: 138.

Bourne RA, Orr RM. 1988. Animal physiology and nutrition. In: R.J. Halley and R.J. Soffe (eds). The Agricultural Notebook. Blackwell Scientific Publication. Oxford, UK.

Kamalak A, Canbolat O, Atalay AI, Kaplan M. 2010. Determination of potential nutritive value of young, old and senescent leaves of Arbutus andrachne tree. J Appl Anim Res, 


\section{Black Sea Journal of Agriculture}

37: 257-260. DOI: 10.1080/09712119.2010.9707136.

Kamalak A, Canbolat O, Ozay 0, Aktas S. 2004. Nutritive value of oak (Quercus spp.) leaves. Small Rumin Res, 53: 161-165.

Kaya E, Kamalak A. 2012. Potential nutritive value and condensed tannin contents of acorns from different oak species. Kafkas Univ Vet Fak Derg, 18(6): 1061-1066.

Khan ZI, Ashraf M, Hussain A. 2007. Evaluation of macro mineral contents of forages: Influence of pasture and seasonal variation. Asian-Australian J Anim Sci, 20(6): 908913.

Kilic U, Boga M, Guven I. 2010. Chemical composition and nutritive value of oak (Quercus robur) nut and leaves. J Appl Anim Res, 38: 101-104.

Mboko AV, Matumuini FNE, Tendonkeng F, Miégoué E, Lemoufouet J, Akagah AA, Boukila B, Pamo ET. 2017. Composition chimique d'arbustes fourragers (Albizia lebbeck, Leucaena leucocephala, Morinda lucida, Senna siamea) en saison sčche au Gabon. Livestock Res Rural Devel, 29: 3.

Mertens D. 2005a. AOAC official method 922.02. In: Horwitz, W., Latimer, G.W. (Eds.), Plants Preparation of Laboratory Sample. Official Methods of Analysis, 18th ed, (Chapter 3). AOAC-International Suite, Gaitherburg, MD, USA, pp: 1-2.

Mertens D. 2005b. AOAC official method 975.03. In: Horwitz, W., Latimer, G.W. (Eds.), Metal in Plants and Pet Foods. Official Methods of Analysis, Official Methods of Analysis, 18th ed, (Chapter 3). AOAC International Suite, Gaitherburg MD, USA, pp: 3-4

NRC. 1980. Mineral tolerance of domestic animals. National
Academy of Sciences. Washington, D.C., US.

NRC. 1985. Nutrient requirements of sheep. National Academy Press, Washington, D.C, US.

Ozkan CO, Atalay AI, Kurt O, Kamalak A. 2016. Effect of species on macro and micro mineral composition of oak leaves with respect to sheep requirements. Livestock Res Rural Devel, 28: 107.

Ozkan CO, Kamalak A, Yilmaz K. 2020. Effect of species on macro and micro mineral composition of some forages with respect to sheep requirements. Livestock Res Rural Devel, 32: 138.

Ozkan CO, Sahin M. 2006. Comparison of in situ dry matter degradation with in vitro gas production of oak leaves supplemented with or without polyethylene glycol (PEG). Asian-Australian J Anim Sci, 19(8): 1120-1126.

Theng K, Preston TR, Ly J. 2003. Studies on utilization of trees and shrubs as the sole feedstuff by growing goats; foliage preferences and nutrient utilization Livestock Res Rural Devel, 15: 50.

Yilmaz K, Gundogan R, Demirkiran AR. 2000. Pedogenesis and classification of soils in Kahramanmaras Province, Turkey. International Symposium on Desertification, ISD, Proceedings p: 517-524. Konya, Turkey.

Ziblim AI, Oppong SK, Danquah E, Collins AN. 2019. Feed intake and animal preference rating of indigenous forage shrub species in the Savanna ecosystem of Ghana. Livestock Res Rural Devel, 31: 100. 